\title{
Notulae to the Italian flora of algae, bryophytes, fungi and lichens: 5
}

Sonia Ravera', Alfredo Vizzini' ${ }^{2,3}$, Annalena Cogoni ${ }^{4}$, Michele Aleffi ${ }^{5}$, Renato Benesperi ${ }^{6}$, Elisabetta Bianchi ${ }^{6}$, Wolfgang von Brackel ${ }^{7}$, Daniela Cataldo ${ }^{8}$, Costantino D'Antonio 9 , Luca Di Nuzzo ${ }^{6}$, Sergio Enrico Favero-Longo ${ }^{2}$, Gabriele Gheza ${ }^{10}$, Deborah Isocrono ${ }^{11}$, Enrica Matteucci' ${ }^{2}$, Stefano Martellos ${ }^{12}$, Lorenzo Morosini ${ }^{12}$, Pier Luigi Nimis ${ }^{12}$, Silvia Ongaro ${ }^{12}$, Silvia Poponessi ${ }^{13}$, Domenico Puntillo ${ }^{14}$, Francesco Sguazzin ${ }^{15}$, Mauro Tretiach ${ }^{12}$

I via del Labaro 54, 00188 Roma, Italy 2 Dipartimento di Scienze della Vita e Biologia dei Sistemi, Università di Torino, Viale P.A. Mattioli 25, 10125 Torino, Italy 3 Institute for Sustainable Plant Protection (IPSP) - CNR, Viale P.A. Mattioli 25, 10125, Torino, Italy 4 Dipartimento di Scienze della Vita e dell'Ambiente, Università degli Studi di Cagliari, viale Sant'Ignazio da Laconi 13, 09123 Cagliari, Italy 5 Scuola di Bioscienze e Medicina Veterinaria, Università degli Studi di Camerino, Unità di Biodiversità Vegetale e Gestione degli Ecosistemi, Laboratorio ed Erbario di Briologia, via Pontoni 5, 62032 Camerino (Macerata), Italy 6 Dipartimento di Biologia, Università di Firenze, Via La Pira 4, 50121 Firenze, Italy 7 Kirchenweg 2, D-91341 Röttenbach, Germany 8 Via Castagne 17, 95017 Piedimonte Etneo (Catania), Italy 9 I.I.S.S. ITN "F. Caracciolo" - IM “G. da Procida”, Via Principe Umberto 40, 80079 Procida (Napoli), Italy 10 Sezione di Ecologia del Territorio, Dipartimento di Scienze della Terra e dell'Ambiente, Università di Pavia, Via S. Epifanio 14, 27100 Pavia, Italy I I Dipartimento di Scienze Agrarie, Forestali e Alimentari, Università di Torino, Largo Paolo Braccini, 10095 Grugliasco (Torino), Italy 12 Dipartimento di Scienze della Vita, Università degli Studi di Trieste, Via L. Giorgieri 10, 34127 Trieste, Italy 13 Dipartimento di Chimica, Biologia e Biotecnologie, Università degli Studi di Perugia, Via del Giochetto 6, 06126 Perugia, Italy 14 Museo di Storia Naturale della Calabria ed Orto Botanico, Università della Calabria, 87036 Arcavacata di Rende (Cosenza), Italy 15 Via Selvotta 61, 33055 Muzzana del Turgnano (Udine), Italy

Corresponding author: Sonia Ravera (sonia.ravera@unimol.it)

Academic editor: Lorenzo Peruzzi | Received 6 March 2018 | Accepted 14 March 2018 | Published 21 March 2018

Citation: Ravera S, Vizzini A, Cogoni A, Aleffi M, Benesperi R, Bianchi E, von Brackel W, Cataldo D, D’Antonio C, Di Nuzzo L, Favero-Longo SE, Gheza G, Isocrono D, Matteucci E, Martellos S, Morosini L, Nimis PL, Ongaro S, Poponessi S, Puntillo D, Sguazzin F, Tretiach M (2018) Notulae to the Italian flora of algae, bryophytes, fungi and lichens: 5. Italian Botanist 5: 31-43. https://doi.org/10.3897/italianbotanist.5.24852

Copyright Sonia Ravera et al. This is an open access article distributed under the terms of the Creative Commons Attribution License (CC BY 4.0), which permits unrestricted use, distribution, and reproduction in any medium, provided the original author and source are credited. 


\begin{abstract}
In this contribution, new data concerning bryophytes, fungi, and lichens of the Italian flora are presented. It includes new records and confirmations for the bryophyte genera Diplophyllum and Ptychostomum, the fungal genera Arrhenia, Gymnosporangium, and Sporidesmium and the lichen genera Arthonia, Coenogonium, Flavoplaca, Gyalolechia, Parmotrema, Peltigera, Pterygiopsis, Squamarina, Tornabea, and Waynea.
\end{abstract}

\title{
Keywords
}

Ascomycota, Basidiomycota, Bryidae, Jungermanniidae, floristic data

\section{How to contribute}

The text of the records should be submitted electronically to: Cecilia Totti (c.totti@ univpm.it) for algae, Annalena Cogoni (cogoni@unica.it) for bryophytes, Alfredo Vizzini (alfredo.vizzini@unito.it) for fungi, Sonia Ravera (sonia.ravera@unimol.it) for lichens.

\section{Floristic records}

\section{BRYOPHYTES}

Errata corrige. Paludella squarrosa (Hedw.) Brid. (Meesiaceae), erroneously reported as new for Trentino-Alto Adige in Ravera et al. (2017), is confirmed to occur in this region, but new only for the mentioned site.

\section{Diplophyllum obtusifolium (Hook.) Dumort. (Scapaniaceae)}

+ FRV: Alta Carnia, (Udine), on moist soil, (UTM WGS84 33T 359573.5156682), ca. 1632 m, 19 October 2014, F. Sguazzin, L. Boemo, A. Boemo (Bryophytorum Herbarium F. Sguazzin). - Species confirmed for the flora of Friuli Venezia Giulia.

Diplophyllum obtusifolium is a montane-arctic-circumpolar liverwort species (Dierßen 2001). It was found together with Sphagnum palustre L., a surprising finding because usually it is a pioneer species colonizing soils banks and track sides (Lockhart et al. 2012). According to Aleffi et al. (2008), the presence in Italy of D. obtusifolium is restricted to a number of northern localities with the only exception of Abruzzo. Its occurrence in Lazio and Marche has not been confirmed over the last 50 years. The herbarium specimen collected by Rossetti and kept in the Herbarium of the University of Pisa (PI) for Toscana (leg. Rossetti, August 1891, Forno Volasco, Apuan Alps) actually refers to Diplophyllum obtusatum (R.M.Schust.) R.M.Schust. (Aleffi et al. 2008). After 114 years since the first report of the species, the present finding is a confirmation for Friuli Venezia Giulia (Bizzozzero 1885, Loitlesberger 1905, Glowacki 1908). This species seems rare in the Mediterranean basin, being recorded only for 
Bosnia-Herzegovina, Bulgaria, Serbia, Spain, France, and Italy (Ros et al. 2007). It was reported from Portugal by Ros et al. (2007), based on a record taken from phytosociological relevés from the Serra da Estrela. After a revision of the material, this record was correctly re-attributed to Diplophyllum taxifolium (Wahlenb.) Dumort. (Ellis et al. 2012). With reference to its global distribution, D. obtusifolium occurs throughout the western part of North America, and is also widespread in Asia, Europe, and eastern North America. According to Hodgetts (2015), it is considered Endangered (EN) in Hungary and Netherlands, Near Threatened (NT) in Luxemburg, Ireland and Italy, Vulnerable (VU) in Germany.

S. Poponessi, F. Sguazzin, M. Aleffi

\section{Ptychostomum subneodamense (Kindberg) J.R.Spence (Bryaceae)}

+ TAA: Kirchbergtal, south of Santa Gertrude (Bolzano) on the right bank of the Kirchbergbach, among the stones and the low vegetation of the stream (UTM WGS84 32T 643004.5147513), 1735 m, 27 June 2017, F. Sguazzin (Bryophytorum Herbarium F. Sguazzin). - Species confirmed for the flora of Trentino-Alto Adige.

The old name Bryum subneodamense Kindb., which was recorded for Italy by Cortini Pedrotti (2001), was considered a synonym of Ptychostomum pseudotriquetrum (Hedw.) J.R.Spence \& H.P.Ramsay by Ros et al. (2013), but later Spence (2013 and in FNA 2014) claimed that P. subneodamense is a distinct species. Ptychostomum subneodamense is a temperate-arctic-circumpolar species; in Europe, it is regionally threatened (Dier $\beta e n$ 2001). Formerly, this species was known only for Valle d'Aosta (Vaccari 1913, sub Bryum neodamense Itzigs. var. ovatum Lindb. \& Arr.), Veneto (Venturi 1899, sub Bryum neodamense Itzigs. var. ovatum Lindb.) and Trentino-Alto Adige (Geheeb 1883, sub Bryum ovatum Jur.; Venturi 1899, sub Bryum neodamense Itzigs. var. ovatum Lindb.). Moreover, Holyoak and Hedenäs (2006) mention a herbarium specimen of Bryum subneodamense Kindberg collected nearby Gorizia (Friuli Venezia Giulia) by Loitlesberger (March 1903, S) and reviewed by Podpěra (1942). Therefore, our record represents the confirmation of the occurrence in Italy of this rare species after 115 years from its last report.

F. Sguazzin

\section{FUNGI}

\section{Arrhenia spathulata (Fr.) Redhead (Hygrophoraceae)}

+ CAL: Bosco di Mavigliano, Montalto Uffugo (Cosenza), on the moss Pleurochaete squarrosa (Brid.) Lindb. (UTM WGS84: 33S 604782.4360104), 200 m, 25 February 2017, D. Puntillo (CLU No. 56); Imbutillo, Curinga (Catanzaro) on the moss $P$. squarrosa (UTM WGS84 33S 606081.4298323) $1 \mathrm{~m}, 24$ November 2017, D. Puntillo (CLU No. 72). - Species new for the flora of Calabria. 
This species is recognizable for its spatuliform, petaliform to flabelliform (fanshaped) basidiome, for its little raised anastomatized and spaced veins, for the short and lateral stipe and for the flexible and wavy margin. Arrhenia spathulata grows on soil with $P$. squarrosa or other mosses. It was known so far from Piemonte (Pollini 1824), Trentino-Alto Adige (Marisa et al. 1986), Toscana (Barluzzi et al. 1996, Perini et al. 1999), Marche (Maletti 2016), Lazio (Granito and Lunghini 2011), Campania (Violante et al. 2002), Sicilia (Signorello and Napoli 1994, Lantieri 2006, Lantieri et al. 2009), Lombardia, Veneto, Emilia-Romagna, and Puglia (Onofri et al. 2005).

D. Puntillo

\section{Gymnosporangium clavariiforme (Wulfen) DC. (Pucciniaceae)}

+ CAL: Piano di Novacco, Saracena (Cosenza), on twigs of Juniperus communis L. (UTM WGS84: 33 5 59506.4406265), 1305 m, 24 May 2014, D. Puntillo (CLU No. 69). - Species new species for the flora of Calabria.

This species is a heteroecious rust, growing on Juniperus as primary host. During spring, it produces a set of orange tentacle-like spore tubes (tetial stage) with a jellylike consistency when wet. The secondary host is Crataegus, where G. clavariiforme produces yellowish depressions on the leaves (spermogonial and aecial stage). The species is widespread in Austria, Belgium, Dalmatia, Finland, Germany, Great Britain, and Hungary (De Toni 1888). In Italy, it has been recorded from Val d'Aosta (Traverso 1912), Trentino-Alto Adige (Hellrigl 2010), and Friuli Venezia Giulia (Tomasi 2014).

D. Puntillo

\section{Sporidesmium bacidiicola Alstrup (Sporidesmiaceae)}

+ SIC: Monte Egitto, Bronte (Catania), western slope of the Etna, in an ancient Quercus congesta forest, on bark, parasitic on Physcia tenella (Scop.) DC. (UTM WGS84: 33 S 493690.4179961), 1550 m, 6 October 2017, leg. D. Cataldo, det. W. v. Brackel (Herb. Brackel 7990). - Species new for the flora of Italy (Sicilia).

The genus Sporidesmium consists of fungi with a mycelium lacking hyphopodia, brown macronematous conidiophores and solitary, euseptate, brown to subhyaline conidia, developing terminally and holoblastic. Most of the species are saprotrophic or parasites of vascular plants and fungi. Only two species are lichenicolous: Sporidesmium lichenicola Iturr., D.Hawksw. \& J.L.Crane, living on Leptogium (Iturriaga et al. 2008), and S. bacidiicola, described from Denmark on Bacidia rubella (Hoffm.) A.Massal. (Alstrup 1991). Later, it was found growing also on Fellhaneropsis vezdae (Coppins \& P.James) Sérus. \& Coppins and on Physcia adscendens H.Olivier and was known until now only from Denmark, Poland, and Germany (Alstrup and Olech 1996, Czyžewska and Kukwa 2009, Alstrup et al. 2013, von Brackel 2014). This species is characterized by effuse colonies, an immersed mycelium, erect, brown, septate, 
proliferating conidiophores, integrated conidiogenous cells, and brown, narrowly ellipsoid, 5-9(-12)-septate conidia.

D. Cataldo, W. v. Brackel

\section{LICHENS}

\section{Arthonia granosa B. de Lesd. (Arthoniaceae)}

+ CAM: Centola (Salerno), on Quercus suber L. (UTM WGS84:32T 526512.4434694), 290 m, 25 February 2011, G. Brunialti, V. Genovesi, S. Ravera. - Species new for the flora of Campania.

It is a rare Mediterranean-Atlantic species, doubtfully lichenized, often collected on cork oak (e.g., Fos 1998, Ravera 2002, Rizzi et al. 2011, Boutabia et al. 2015). It is a characteristic lichen of the Arthonietum granosae Giralt \& Gómez-Bolea 1987, an epiphytic community restricted to coastal stations with humid maritime winds. Arthonia granosa can be distinguished from other superficially similar Arthonia species by the white pruina on the round to oblong apothecia, hymenium I+ wine coloured and 1-septate guttulate spores $18-30 \times 8-13 \mu \mathrm{m}$. In Italy, the species has been reported from Lazio, Sardegna, Puglia (Nimis 2016) and Sicilia (Ottonello et al. 2011). Due to its rarity, it is included in the Italian red list of epiphytic lichens under the "Vulnerable" category (Nascimbene et al. 2013).

S. Ravera

\section{Coenogonium luteum (Dicks.) Kalb \& Lücking (Coenogoniaceae)}

+ TOS: Marina di Castagneto Carducci (Livorno), on Juniperus macrocarpa Sm. (UTM WGS84: 32T 624680.4784765), 8 m, 24 November 2017, L. Di Nuzzo, E. Bianchi, $R$. Benesperi. - Species confirmed for the flora of Toscana.

Coenogonium luteum is a crustose pantropical lichen with orange to pink apothecia and green thallus. Its distribution includes both hemispheres; in Italy, it is a mostly Tyrrhenian species (Nimis 2016). It occurs in shaded situations and, due to its rarity, it is included in the Italian red list of epiphytic lichens under the "Least Concern" category (Nascimbene et al. 2013).

L. Di Nuzzo, E. Bianchi, R. Benesperi

\section{Flavoplaca limonia (Nimis \& Poelt) Arup, Frödén \& Søchting (Teloschistaceae)}

+ FVG: Castle of San Giusto (Trieste), near the entrance on inclined surfaces of calciferous sandstone (UTM WGS84: 32N 871998.5066124), 80 m, 25 January 2016, P.L. Nimis (TSB No. 47501). - Species new for the flora of Friuli Venezia Giulia. 
It is a species of the $F$. citrina-complex, characterised by large soredia/blastidia, a limonia-type of soralium, a pale yellow thallus, and a thick apothecial margin often covered by blastidia. Flavoplaca limonia is found on calcareous rocks or on base-rich, hard, siliceous cliffs in dry and in sun-exposed to shaded and damp situations, but also on twigs of maritime shrubs or on soil, below the montane belt. This species, described from calcareous cliffs along the coast of the Island of Marettimo, Sicilia (Nimis et al. 1994), proved to be quite widespread in southern Europe (see, e.g., Vondrák et al. 2009). Its hitherto known Italian distribution was limited to coastal localities of Puglia, Sicilia, and Sardegna, and an inland locality in Veneto (Nimis 2016), but the species is certainly more widespread, since in the past it was generally identified as "Caloplaca citrina".

P.L. Nimis

\section{Gyalolechia fulgida (Nyl.) Søchting, Frödén \& Arup (Teloschistaceae)}

+ PIE: Gremiasco (Alessandria), surroundings of the Osservatorio Astronomico Cà del Monte, on south-facing sandstone outcrops (UTM WGS84: 32T 506270.4962306), 682-687 m, 9 December 2016, G. Gheza (Herb. Gheza); Monte Vallassa (Alessandria), on a southeast-facing sandstone outcrop in the woods (UTM WGS84: 32T 507119.4962675), 725 m, 9 December 2016, G. Gheza (Herb. Gheza). - Species new for the flora of Piemonte.

+ LOM: surroundings of Agriturismo Guardamonte, Bagnaria (Pavia), on a southeastfacing sandstone rock face (UTM WGS84: 32T 507608.4962932), 720 m, 10 August 2016, G. Gheza (Herb. Gheza). - Species new for the flora of Lombardia.

Gyalolechia fulgida is a Mediterranean species found mainly on calcareous rocks in the Mediterranean belt (Nimis 2016). It was previously known for northern Italy only in one site in Liguria (Valcuvia Passadore et al. 2000). The three new sites recorded here, extending the Italian range of the species to Piemonte and Lombardia, are actually very close, being located on two mountainsides with the thermo-xeric character of a mountain placed along the boundary between Val Curone (Alessandria) and Val Staffora (Pavia). In these sites, G. fulgida was found together with the lichens Placidium sp., Squamarina cartilaginea (With.) P.James, Squamarina stella-petraea Poelt and with the moss Grimmia sp., in more or less sheltered concavities of sandstone outcrops, both on the thin soil layer over weathered sandstone and on the very rock.

G. Gheza

\section{Parmotrema hypoleucinum (J. Steiner) Hale (Parmeliaceae)}

+ CAM: Isola di Vivara, Procida (Napoli), on twigs of Erica arborea L. and Olea europaea L. (UTM WGS84: 33T 415034.4510875), 13 October 2008, C. D’Antonio (TSB No. 47500). - Species new for the flora of Campania.

This is a pantropical-pantemperate species with a Mediterranean-Atlantic distribution in Europe, found on twigs of trees and shrubs in undisturbed Mediterranean 
maquis vegetation along the coasts, which can be easily distinguished from all other Parmotrema-species occurring in Italy by the white lower surface. It is a characteristic lichen of a rare and endangered epiphytic community, which is most frequent on undisturbed, coastal sand dunes, the Parmotremetum reticulati-hypoleucini Nimis \& Schiavon (1986). Its distribution in Italy is predominantly Tyrrhenian, the species having been reported from Toscana, Lazio, Sardegna, Puglia, Basilicata and Calabria (Nimis 2016). The species is generally very rare and is, therefore, included in the Italian red list of epiphytic lichens as "Near-threatened" (Nascimbene et al. 2013). It is certainly declining, due to increasing touristic exploitation of coastal environments. The new record fills a gap in its distribution along the Tyrrhenian coasts of the Italian Peninsula.

P.L. Nimis, C. D’Antonio

\section{Peltigera monticola Vitik. (Peltigeraceae)}

+ PIE: Oropa (Biella), near the Santuario, on soil (UTM WGS84: 32T 420405.5053261), $1150 \mathrm{~m}$, summer 1905, leg. L. Micheletti det. D. Isocrono, E. Matteucci, S.E. Favero-Longo (TO n. 3412); Crissolo (Torino), Pian del Re, near Fiorenza Lake, (UTM WGS84: 32T 348927.4951186), 2150 m, 10 September 2012, on serpentinite outcrops D. Isocrono, E. Matteucci, S.E. Favero-Longo (TO n. 2118). - Species new for the flora of Piemonte.

Peltigera monticola is a terricolous species, first described by Vitikainen (Vitikainen 1994), belonging to the large Peltigera canina group, a species complex that includes taxa that are sometimes difficult to identify (Miadlikowska et al. 2003) and, for this reason, often misunderstood. It is considered rare in Italy, where it has been reported for the Eastern Alps and Sardinia (Nimis 2016). The records reported here are the first for the Italian Western Alps. The first record from Piemonte is available through a herbarium specimen collected by Luigi Micheletti near Oropa and previously identified as Peltigera canina (L.) Willd.

D. Isocrono, E. Matteucci, S.E. Favero-Longo

\section{Pterygiopsis affinis (A.Massal.) Henssen (Lichinaceae)}

+ MAR: Gole della Rossa, Fabriano (Ancona), on calcareous rock (UTM WGS84: 33T 338355.4810338), 200 m, 3 November 2017, L. Morosini. - Species new for the flora of Marche.

+ UMB: Monte di Pale, Foligno (Perugia), near the Eremo di Santa Maria Giacobbe on calcareous rock (UTM WGS84: 33T 318298.4761664), 520 m, 30 August 2017, L. Morosini. - Species new for the flora of Umbria.

+ BAS: Parco dei Monaci (Matera), along Gravina stream on calcareous rock (UTM WGS84: 33T 639479.4496784), 130 m, 10 June 2016, M. Tretiach, S. Ongaro; Parco dei Monaci (Matera), along the Gravina stream on calcareous rock (UTM WGS84: 33T 640142.4495777), 125 m, 10 June 2016, M. Tretiach, S. Ongaro; Province of 
Matera, on a calcareous rock wall (UTM WGS84: 33T 640199.4496976), 195 m, 10 June 2016, M. Tretiach, S. Ongaro; Contrada Murgia Timone (Matera), on calcareous rock (UTM WGS84: 33T 636965.4502634), $380 \mathrm{~m}, 10$ June 2016, M. Tretiach, S. Ongaro. - Species new for the flora of Basilicata.

Pterygiopsis affinis is the only species of the genus Pterygiopsis known to occur in Italy. The genus is part of the family Lichinaceae, which includes several genera, with varied morphology and different photobionts. Some genera are particularly difficult to identify, and their taxonomic position is debatable. Pterygiopsis affinis is a crustose lichen with a placodioid, effigurate thallus, from bluish black to dark grey. Apothecia are lecanorine, with proper margin and red disc. Asci are multi-spored, with hyaline, sub-globose to broadly ellipsoid ascospores, ca. 6-12 × 3-6 $\mu \mathrm{m}$. The photobiont is a chroococcoid, unicellular cyanobacterium (Gloeocapsa), with a yellowish mucilaginous cell envelope. Pterygiopsis affinis is a rare epilithic lichen, tolerating high solar radiation and prolonged drought. It grows on south-exposed rocks, often along seepage tracks. In Italy, P. affinis occurs from the Alpine regions to Puglia and Sardegna, but owing to lack of knowledge in several Regions (Nimis 2016), its frequency has been certainly underestimated.

S. Ongaro, L. Morosini, S. Martellos, M. Tretiach

\section{Squamarina stella-petraea Poelt (Squamarinaceae)}

+ PIE: Gremiasco (Alessandria), surroundings of the Osservatorio Astronomico Cà del Monte, on south-facing sandstone outcrops (UTM WGS84: 32T 506270.4962306), 682-687 m, 9 December 2016, G. Gheza (Herb. Gheza). - Species confirmed for the flora of Piemonte.

+ LOM: surroundings of Agriturismo Guardamonte, Bagnaria (Pavia), on a southeastfacing sandstone rock face (UTM WGS84: 32T 507608.4962932), 720 m, 10 August 2016, G. Gheza (Herb. Gheza). - Species new for the flora of Lombardia.

Squamarina stella-petraea is a Mediterranean species found mainly on calcareous rocks in the Mediterranean belt (Nimis 2016). It can be quite easily distinguished from other saxicolous Squamarina because of its rosulate white thallus, areolate in the middle and lobed at the margin. It was previously known for northern Italy only in one site in Piemonte (Nimis 2016) and one in Liguria (Valcuvia Passadore et al. 2000). The two new sites recorded here, extending to Lombardia the Italian range of the species, are located on two mountainsides of Monte Vallassa with thermo-xeric character. Here, S. stella-petraea was found together with Squamarina cartilaginea (With.) P.James, Romjularia lurida (Ach.) Timdal, and Gyalolechia fulgida (Nyl.) Søchting, Frödén \& Arup in more or less sheltered concavities of sandstone outcrops. It was found with well-developed rosulate thalli, but also coalesced with $S$. cartilaginea.

G. Gheza 


\section{Tornabea scutellifera (With.) J.R. Laundon (Physciaceae)}

+ TOS: Marina di Castagneto Carducci (Livorno), on Juniperus macrocarpa Sm. (UTM WGS84: 32T 624591.4785396), 6 m, 10 July 2017, L. Di Nuzzo, E. Bianchi, R. Benesperi; Marina di Castagneto Carducci (Livorno), on J. macrocarpa (UTM WGS84: 32T 624680.4784765), 8 m, 24 November 2017, L. Di Nuzzo, E. Bianchi, R. Benesperi. - Species confirmed for the flora of Toscana.

Tornabea scutellifera is a fruticose epiphytic macrolichen strictly associated with semiarid and warm situations with frequent periods of high air humidity (Nimis and Tretiach 1997). It is included in the Italian red list of epiphytic lichens under the "Least Concern" category (Nascimbene et al. 2013). There are no recent records in the literature for Toscana (Micheli 1729; Savi 1825; Baglietto 1871; Saccardo 1894).

L. Di Nuzzo, E. Bianchi, R. Benesperi

\section{Waynea giraltiae van den Boom (Ramalinaceae)}

+ SIC: Monte Egitto, Bronte (Catania), western slope of the Etna, in an ancient Quercus congesta forest, on bark (UTM WGS84: 33S 493690.4179961), 1550 m, 6 October 2017, leg. D. Cataldo, det. W. v. Brackel (Herb. Brackel 7197). - Species new for the flora of Italy (Sicilia).

Waynea giraltiae was recently described from Portugal; it was known until now only from the Iberian Peninsula (Portugal and Spain), growing in the lowland on the bark of Quercus rotundifolia Lam. (van den Boom 2010). This species is characterized by a squamulose to granulose thallus with thick-walled, hyaline, septate hairs, a welldefined upper cortex, marginate, greyish to blackish apothecia, asci Bacidia-type and hyaline, fusiform, (1-)3-septate ascospores, $12-18 \times 2-2.5 \mu \mathrm{m}$. Sterile specimens may be mistaken for Agonimia opuntiella (Buschardt \& Poelt) Vězda, but this species lacks the thick hyaline upper cortex, the hairs are composed of several hyphae and the upper surface is papillate. Sterile Physconia servitii (Nádv.) Poelt has a similar appearance, but also in this species, the hairs are composed of several strands of hyphae and the thallus is whitish-grey instead of greenish.

D. Cataldo, W. V. Brackel

\section{Acknowledgements}

Daniela Cataldo and Wolfgang von Brackel wish to thank Stefan Ekman (Uppsala/ Sweden) and Pieter van den Boom (Arafura/The Netherlands) for hints on the identification of Waynea giraltiae. 


\section{References}

Aleffi M, Tacchi R, Cortini Pedrotti C (2008) Check-list of the Hornworts, Liverworts and Mosses of Italy. Bocconea 22: 1-255.

Alstrup V (1991) Sporidesmium bacidiicola sp. n. Graphis Scripta 3: 44-45.

Alstrup V, Olech M (1996) Lichenicolous fungi of the Polish Tatra Mountains. Fragmenta Floristica et Geobotanica 41: 747-752.

Alstrup V, Søchting U, Dragsholt C, Læssøe T, Thell A, Kukwa M (2013) Additions to the lichens and lichenicolous fungi of Denmark 8. Graphis Scripta 25: 56-63.

Baglietto F (1871) Prospetto Lichenologico della Toscana. Nuovo Giornale Botanico Italiano 3: 211-298.

Barluzzi C, Bellù F, Comandini O, Padovan F, Perini C (1996) Studi micofloristici nella Riserva Naturale del Lago di Burano (GR). Elenco micofloristico. Pagine di Micologia 6: 62-73.

Bizzozzero G (1885) Flora Veneta Crittogamica. Tip. del Seminario. Padova, 572 pp.

Boutabia L, Telailia S, de Belair G (2015) Corticolous lichen flora on Quercus suber L. in the wetlands of El Kala national park (North-Eastern Algeria). Advances in Environmental Biology 9: 360--372.

Brackel von W (2014) Kommentierter Katalog der flechtenbewohnenden Pilze Bayerns. Bibliotheca Lichenologica 109: 1-476.

Cortini Pedrotti C (2001) Flora dei muschi d'Italia, I parte. Antonio Delfino Editore. Sassari. 832 pp.

Czyžewska K, Kukwa M (2009) Lichenicolous fungi of Poland. A catalogue and key to species. Biodiversity of Poland 11: 1-133.

De Toni GB (1888). Sylloge ustilaginearum et uredinearum. Sylloge Fungorum 7: 738.

Dierßen K (2001) Distribution, ecological amplitude and phytosociological characterization of European bryophytes. Bryophytorum Biblioteca 56: 1-289.

Ellis LT, Alegro A, Bansal P, Nath V, Cykowska B, Bednarek-Ochyra H, Ochyra R, Dulin MV, Erzberger P, Garcia C, Sérgio C, Claro D, Stow S, Hedderson TA, Hodgetts NG, Hugonnot V, Kucera J, Lara F, Pertierra L, Lebouvier M, Liepina L, Mežaka A, Strazdiña L, Madžule L, Rēriha I, Mazooji A, Natcheva R, Phephu N, Philippov DA, Plášek V, Čihal L, Pócs T, Porley RD, Sabovljevic M, Salimpour F, Berhroozmand Motlagh M, Sharifnia F, Akhoondi Darzikolaei S, Schäfer-Verwimp A, Segota V, Shaw AJ, Sim-Sim M, Sollman P, Spitale D, Hölzer A, Stebel A, Váňa J, van Rooy J, Vončina G (2012) New national and regional bryophyte records, 32. Journal of Bryology 34: 231-246. https://doi.org/10.117 9/1743282012Y.0000000019

FNA [Flora of North America Editorial Committee] (2014) Flora of North America North of Mexico - Bryophytes: Mosses, part 2. New York and Oxford, 165 pp.

Fos S (1998) Líquenes epífitos de los alcornocales ibéricos. Correlaciones bioclimáticas, anatómicas y densimétricas con el corcho de reproducción. Guineana 4: 1-507.

Geheeb A (1883) Bryologische Fragmente II. Flora 66: 483-491.

Glowacki J (1908) Ein Beitrag zur Kenntnis der Laubmoosflora von Karnten. Jahrbuch Naturhistorischen Museum 28: 165-186.

Granito VM, Lunghini D (2011) Biodiversity of macrofungi in the beech forests and calcareous grasslands of the Simbruini Mountains Regional Park (central Apennines, Italy). Plant Biosystems 145: 381-396. https://doi.org/10.1080/11263504.2011.563523 
Hellrigl K (2010) Pflanzengallen und Gallenkunde - Plant Galls and Cecidology. Forest Observer 5: 214 .

Hodgetts NG (2015) Checklist and country status of European bryophytes - towards a new Red List for Europe. Irish Wildlife Manuals, No. 84. National Parks and Wildlife Service, Department of Arts, Heritage and the Gaeltacht, Ireland, 130 pp.

Holyoak DT, Hedenäs L (2006) Morphological, ecological and molecular studies of intergrading taxa Bryum neodamense and B. pseudotriquetrum (Bryopsida: Bryaceae). Journal of Bryology 28: 299-311. https://doi.org/10.1179/174328206X136304

Iturriaga T, Hawksworth DL, Crane JL (2008) 'Sporidesmium' lichenicola sp. nov., a new lichenicolous fungus on Leptogium from Venezuela. Mycologia 100: 392-396. https://doi. org/10.3852/06-166R

Lantieri A (2006) Studio sulle specie fungine del litorale sabbioso della Riserva Naturale Orientata di Vendicari (Sicilia). Informatore Botanico Italiano 38: 129-135.

Lantieri A, Gargano ML, Venturella G (2009) The sabulicolous fungi from Sicily (southern Italy): additions and critical review. Mycotaxon 110: 151-154. https://doi. org/10.5248/110.151

Lockhart N, Hodgetts N, Holyoak D (2012) Rare and threatened bryophytes of Ireland. National Museums of Northern Ireland, Holywood. 656 pp.

Loitlesberger K (1905) Zur Moosflora der österreichischen Küstenländer. Verhandlungen Zoologisch-Botanisch Gesellschaft Wien 59: 51-67.

Maletti M (2016) Funghi del litorale pesarese (Parte 2a). Micologia nelle Marche 10: 17-24.

Marisa G, Merighi D, Posanti L (1986). Elenco sistematico di alcuni basidio-, asco-, mixomiceti finora rinvenuti nel territorio di Rovereto e dintorni (Trentino meridionale). IIa parte. Annali del Museo Civico di Rovereto 2: 115-158.

Miadlikowska J, Lutzoni F, Goward T, Zoller S, Posada D (2003) New approach to an old problem: Incorporating signal from gap-rich regions of ITS and rDNA large subunit into phylogenetic analyses to resolve the Peltigera canina species complex. Mycologia 95: 11811203. https://doi.org/10.1080/15572536.2004.11833027

Micheli PA (1729) Nova Plantarum Genera. Tip. Paperinii. Firenze, 234 pp.

Nascimbene J, Nimis PL, Ravera S (2013) Evaluating the conservation status of epiphytic lichens of Italy: a red list. Plant Biosystems 147: 898-904.https://doi.org/10.1080/11263 504.2012.748101

Nimis PL (2016) The Lichens of Italy. A second annotated catalogue. EUT, Trieste, 740 pp.

Nimis PL, Schiavon L (1986) The epiphytic lichen vegetation of the Tyrrhenian coasts in Central Italy. Annali di Botanica 41: 39-67.

Nimis PL, Tretiach M (1997) A revision of Tornabea, agenus offruticoselichens new to North America. The Bryologist 100: 217-225. https://doi.org/10.1639/0007-2745(1997)100[217:AROTAG]2.0.CO;2

Nimis PL, Poelt J, Tretiach M, Ottonello D, Puntillo D, Vezda A (1994) Contributions to lichen floristics in Italy. VII. The Lichens of Marettimo (Egadi Islands, Sicily). Bulletin de la Société Linnéenne de Provence 45: 247-262.

Onofri S, Bernicchia A, Filipello Marchisio V, Padovan F, Perini C, Ripa C, Salerni E, Savino E, Venturella G, Vizzini A, Zotti M, Zucconi L (2005) Check-list dei funghi italiani. Basidiomycetes. Carlo Delfino Editore, Sassari, 384 pp. 
Ottonello D, Puntillo D, Compagno R (2011). Contributo alla conoscenza dei licheni e funghi lichenicoli di Pantelleria (Trapani, Sicilia, Italia). Micologia Italiana 40: 32-55.

Perini C, Narducci R, Barluzzi C, Laganà A, Salerni E (1999) I Funghi in Toscana. Allegato 1.

Elenco delle specie censite in Toscana. In: Tofacchi L, Mannini M, AGMT, ARSIA (Eds) I

funghi in Toscana. Mappatura e censimento dei macromiceti epigei. Bandecci \& Vivaldi, Pontedera, Pisa, 73-98.

Podpĕra J (1942) Bryum generis monographiae prodromus I. Species Eurasiae septentrionalis,

Part I. Acta Societatis Scientiarum Naturalium Moravicae (Brno) 14: 1-58.

Pollini C (1824) Flora veronensis quam in prodromum florae Italiae septentrionalis. Typis et Expensis Societatis Typographicae. Verona. 3: 628.

Rizzi G, Incerti G, Ginaldi F, Kodnik D, Viglione S, Giordani P (2011) A contribution to the lichen flora of Sardinia. Mycotaxon 115: 535.

Ravera S, Vizzini A, Cogoni A, Aleffi M, Assini S, Bergamo Decarli G, Bonini I, von Brackel W, Cheli F, Darmostuk V, Fačkovcová Z, Gavrylenko L, Gheza G, Guttová A, Mayrhofer H, Nascimbene J, Paoli L, Poponessi S, Potenza G, Prosser F, Puddu D, Puntillo D, Rigotti D, Sguazzin F, Tatti A, Venanzoni R (2017) Notulae to the Italian flora of algae, bryophytes, fungi and lichens: 4. Italian Botanist 4: 73-86. https://doi.org/10.3897/ib.4.21671

Ros RM, Mazimpaka V, Abou-Salama U, Aleffi M, Blockeel T L, Brugués M, Cros RM, Dia MG, Dirkse GM, Draper I, El-Saadawi W, Erdag A, Ganeva A, Gabriel R, GonzalesMancebo JM, Granger C, Herrnstadt A, Hugonnot V, Khalil K, Kürschner H, LosadaLima A, Luís L, Mifsus S, Privitera M, Puglisi M, Sabovlijević, Sèrgio C, Shabbara HM, Sim-Sim M, Sotiaux A, Tacchi R, Vanderpoorten A, Wernner O (2013) Mosses of the Mediterranean, an annotated checklist. Cryptogamie, Bryologie 34: 99-283. https://doi. org/10.7872/cryb.v34.iss2.2013.99

Saccardo F (1894) Saggio di una flora analitica dei licheni del Veneto, aggiuntavi l'enumerazione sistematica di altre specie italiane. Tip. Prosperini. Padova, 164 pp.

Savi G (1825) Botanicon Etruscum: Sistens Plantas in Etruria Sponte Crescentes. Vol. 4. Tip.

Prosperi. Pisa, 320 pp.

Signorello P, Napoli M (1994) Macromiceti della Sicilia: quarto contributo. Bollettino dell'Accademia Gioenia Scienze Naturali Catania 27(346): 171-199.

Spence JR (2013) A new combination in Ptychostomum (Bryaceae, Bryophyta) for Bryum subneodamense Kindb. Phytoneuron 3: 1.

Tomasi E (2014) Indagine cecidologica sulla pianura e le lagune friulane (Italia NE). Atti del Museo Civico di Storia Naturale di Trieste 56: 115.

Traverso GB (1912) Manipolo di Funghi della Valle Pellina. Bulletin de la Société de la Flore Valdôtaine 8: 39.

Vaccari L (1913) Contributo alla briologia della Val d'Aosta. Nuovo Giornale Botanico Italiano 20: 417-496.

Valcuvia Passadore M, Chiappetta D, Terzo V (2000) Florula lichenica della valle del Torrente Caramagna (Imperia - Liguria Occidentale). Notiziario della Società Lichenologica Italiana 13: 24-25.

van den Boom PPG (2010) Waynea giraltiae, a new lichen species from the Iberian Peninsula. Lichenologist 42: 29-33. https://doi.org/10.1017/S0024282909990326 
Venturi G (1899) Le Muscinee del Trentino. Tip. G. Zippel, Trento, 71-72.

Violante U, Roca E, Violante M, Soriente S, Pizzolongo F (2002) Micoflora della Campania: check-list dei macrofungi. Informatore Botanico Italiano 34: 3-34.

Vitikainen O (1994) Taxonomic revision of Peltigera (lichenized Ascomycotina) in Europe. Acta Botanica Fennica 152: 1-96.

Vondrák J, Riha P, Arup U, Søchting U (2009) The taxonomy of the Caloplaca cirina group (Teloschistaceae) in the Black Sea region; with contributions to the cryptic species concept in lichenology. Lichenologist 41: 571-604. https://doi.org/10.1017/S0024282909008317 